Research Article

www.ijrap.net

\title{
ANTIFUNGAL EFFECT OF CLITORIA TERNATEA L. LEAF EXTRACT ON SEEDS OF PISUM SATIVUM L. IN RELATION TO THE ACTIVITIES OF SOME ENZYMES
}

Das Neela and Chatterjee Padma*

Plant Biochemistry, Molecular Biology and Advance Plant Physiology Research Laboratory, Department of Botany, University of Kalyani, Kalyani, Nadia, West Bengal, India

Received on: 29/11/13 Revised on: 24/01/14 Accepted on: 24/02/14

\author{
*Corresponding author \\ Prof. Padma Chatterjee, Department of Botany, University of Kalyani, Kalyani, Nadia 741235, West Bengal, India \\ Email: schatterjeecal2003@yahoo.co.in \\ DOI: $10.7897 / 2277-4343.05120$
}

\section{ABSTRACT}

This paper highlights the antifungal activities of the leaf extract of Clitoria ternatea L. against Fusarium oxysporum ciceri. The experimental procedures include study of the activities of some marker enzymes of seeds of Pisum sativum L. The leaf extract of Clitoria showed antifungal activity in relation to some enzyme activities. Fungus infestation increased activity level of some stress enzymes like catalase, peroxidase and Superoxide Dismutase which was controlled by the administration of the plant extract. Furthermore the activities of amylase, protease and dehydrogenase were decreased by the fungal infestation which was overcome by application of the plant extract. The findings of the work thus supports that the formulation can be used as an antifungal agent against the fungus to overcome the deleterious effect caused by it on the pea seeds.

Keywords: antifungal, antimicrobial formulation, stress, enzyme activity, infestation

\section{INTRODUCTION}

In last few decades, extensive research has been done to find out various bioactive compounds having antimicrobial effects. From the era of Charak, Sushruta various plants have been used as therapeutic agents. Different types of measures have been employed for controlling phytopathogenic fungi. The use of synthetic fungicides causes extreme damage to the ecosystem and mankind. These fungi may later become resistant to those compounds. At this stage, some alternative remedies are in demand. Some of the traditional medicine involves the use of crude plant extracts, which may contain an extensive diversity of molecules, often with indefinite biological effects ${ }^{1}$. C. ternatea L. commonly known as Butterfly pea belonging to the family Fabaceae and subfamily Papilionaceae is a perennial leguminous twinner, which originated from tropical Asia and later was distributed widely in South and Central America, East and West Indies, China and India, where it has become naturalised. It is also commonly called as Clitoria, blue-pea, kordofan pea (Sudan), cunha (Brazil or pokindong (Philippines) and is a vigorous, summer growing, legume of old world origin. The most frequently reported species is $C$. ternatea $\mathrm{L}$. The major phytoconstituents found in the plant are the pentacyclic triterpenoids such as taraxerol and taraxerone ${ }^{2,3}$. The seeds contain nucleoprotein with its amino-acid sequence similar to insulin, delphinidin-3,3,5-triglucoside, essential amino-acids, pentosan, water soluble mucilage, adenosine, an anthoxanthin glucoside, greenish yellow fixed oil ${ }^{4,5}$ a phenol glycoside, 3,5,7,4-tetrahydroxy-flavone-3-rhamoglycoside, an alkaloid, ethyl D-galactopyranoside, p-hydroxy cinnamic acid polypeptide, a highly basic protein-finotin, a bitter acid resin, tannic acid, $6 \%$ ash and a toxic alkaloid. According to Yoganarasimhan seeds contain $\beta$-sitosterol, and hexacosanol and anthocyanin glucoside ${ }^{6-9}$. It also contains anti-fungal proteins and has been shown to be homologous to plant defensins ${ }^{10}$. Since the purified lectin was found to be potential tool for cancer studies so an attempt was made for the alternate high yielding purification method for $C$. ternatea lectin designated CTL, present in the seeds of this member of leguminosae family ${ }^{11,12}$. The present work may be cited as an initial platform for a reply to such a demand, where we tried to find out the anti microbial effect of the leaf extract of Clitoria ternatea L. plant against $F$. oxysporum ciceri that acts as a destructive pathogen of Pisum sativum L. plants hindering its productivity. In this paper we tried to establish the antifungal efficiency of $50 \%$ aqueous extract of Clitoria ternatea L. against Fusarium oxysporum ciceri in Pisum sativum L. seeds in relation to the activities of some marker enzymes of metabolism. The study also entailed isolation of a purified bioactive sample and its antifungal potentiality in terms of the studied enzymes.

\section{MATERIALS AND METHODS}

Clitoria ternatea L. plants were collected. The foliar parts of the plant materials were dried, powered and stored. The Pisum sativum L. seeds of local variety were collected from Bidhan Chandra Krishi Visvavidyala. Micro-organism used: Fusarium oxysporum ciceri collected from the departmental stock culture, Department of Botany, University of Kalyani, Kalyani, Nadia, West Bengal, India. The fungi was grown on PDA medium ( $\mathrm{pH}-6.8$ ) and incubated at $28^{\circ} \mathrm{C}$, Department of Botany, University of Kalyani.

\section{Preparation of plant extract}

$100 \mathrm{~g}$ of dried powered leaves of Clitoria ternatea L. were sequentially soaked in petroleum ether $\left(60-80^{\circ} \mathrm{c}\right)$, chloroform and $50 \%$ aqueous ethanol for seven days. The extracts were collected separately, evaporated under reduced pressure in a vacuum rotary evaporator. Dark green and brown residual solids collected from each fraction were subjected to agar cup diffusion bioassay method ${ }^{13}$ against Fusarium oxysporum ciceri. Activity was located in $50 \%$ aqueous ethanolic fraction. Seeds of Pisum sativum L. plants were taken up as experimental material for in vitro studies. Six different sets were maintained by presoaking the seeds with water, plant extract (applied following MIC $60 \mathrm{mg} / \mathrm{ml}$ ) and fungicide (100 
$\mathrm{mg} / \mathrm{ml}$ ) for 3 hours. After that half of the seeds from each set were exposed to fungal inoculum.

\section{Determination of enzyme activities}

The enzyme activities were calculated by the Fick and Qualset, (1975) formula ${ }^{14}$ :

Enzyme activity $=\Delta$ O.D. $* \mathrm{tv} / \mathrm{T} * \mathrm{v} * \mathrm{w}$

Where, $\Delta \mathrm{OD}=$ difference in OD. Values, $\mathrm{tv}=$ total volume of extract, $\mathrm{v}=$ volume of enzyme taken for reaction, $\mathrm{w}=$ weight of tissue used, $\mathrm{T}=$ total time
Following enzymes were studied:

- Amylase: Khan and Faust, $1967^{15}$,

- Catalase: Snell and Snell, $1971^{16}$, modified by Biswas and Choudhuri, $1978^{17}$,

- Dehydrogenase: Rudrapaul and Basu, $1979^{18}$,

- Peroxidase: Chance and Maehly, $1955^{19}$, modified by Kar and Mishra, $1976^{20}$,

- Protease: Biswas and Choudhury, $1978^{21}$,

- Superoxide Dismutase (SOD): Method of Asada et al. $1974^{22}$

Table 1: General screening of petroleum ether, chloroform and $50 \%$ aqueous ethanolic extract against Fusarium oxysporum ciceri

\begin{tabular}{|c|c|c|}
\hline Clitoria ternatea $\mathbf{L}$. & Diameter of inhibition zone (cm) & Inhibition percentage (\%) \\
\hline Petroleum ether & - & - \\
\hline Chloroform & - & - \\
\hline $50 \%$ ethanol & 0.5 & 17.0 \\
\hline
\end{tabular}

Table 2: Studies on the effect of $50 \%$ aq. ethanolic extract and bioactive sample on amylase and protease activity in Pisum sativum L. seeds

\begin{tabular}{|c|c|c|c|c|c|c|}
\hline Treatment sets & \multicolumn{3}{|c|}{ Amylase activity } & \multicolumn{3}{c|}{ Protease activity } \\
\hline & after 24 h & after 48 h & after 72 h & after 24 h & after 48 h & after 72 h \\
\hline Healthy & $5054.8 \pm 31.8$ & $3235.4 \pm 16.1$ & $2082.9 \pm 13.0$ & $942.484 \pm 7.217$ & $718.265 \pm 7.257$ & $599.684 \pm 5.782$ \\
\hline Fungus infested & $4786.0 \pm 140.8$ & $1710.8 \pm 17.3$ & $1170.4 \pm 8.7$ & $600.517 \pm 5.797$ & $609.959 \pm 2.887$ & $439.785 \pm 2.895$ \\
\hline Fungus infested $+60 \mathrm{mg} / \mathrm{ml} \mathrm{F}$ & $4901.7 \pm 13.0$ & $3313.8 \pm 13.1$ & $2815.2 \pm 8.7$ & $714.738 \pm 5.779$ & $541.237 \pm 74.048$ & $517.550 \pm 4.330$ \\
\hline Healthy $+60 \mathrm{mg} / \mathrm{ml} \mathrm{F}$ & $6454.8 \pm 29.3$ & $3017.7 \pm 13.0$ & $2975.2 \pm 14.4$ & $725.135 \pm 4.330$ & $625.817 \pm 4.183$ & $602.416 \pm 10.104$ \\
\hline Healthy gresiofulvin treated & $6029.9 \pm 25.0$ & $5056.8 \pm 47.5$ & $4595.0 \pm 20.0$ & $240.289 \pm 2.901$ & $72.357 \pm 1.450$ & $209.166 \pm 2.619$ \\
\hline $\begin{array}{c}\text { Fungus infested + gresiofulvin } \\
\text { treated }\end{array}$ & $4947.1 \pm 45.1$ & $3644.3 \pm 22.7$ & $2150.0 \pm 15.0$ & $565.314 \pm 2.904$ & $129.792 \pm 2.042$ & $448.220 \pm 4.390$ \\
\hline
\end{tabular}

Table 3: Studies on the effect of $50 \%$ aq. ethanolic extract and bioactive sample on dehydrogenase and peroxidase activity in Pisum sativum L. seeds

\begin{tabular}{|c|c|c|c|c|c|c|}
\hline Treatment sets & \multicolumn{3}{|c|}{ Dehydrogenase activity } & \multicolumn{3}{c|}{ Peroxidase activity } \\
\hline & after $\mathbf{2 4} \mathbf{~ h}$ & $\mathbf{a f t e r} \mathbf{4 8} \mathbf{~ h}$ & $\mathbf{a f t e r} \mathbf{7 2} \mathbf{~ h}$ & $\mathbf{a f t e r} \mathbf{2 4} \mathbf{~ h}$ & $\mathbf{a f t e r} \mathbf{4 8} \mathbf{~ h}$ & $\mathbf{a f t e r} \mathbf{7 2} \mathbf{~ h}$ \\
\hline Healthy & $88.790 \pm 0.680$ & $461.937 \pm 1.488$ & $148.460 \pm 0.680$ & $0.497 \pm 0.012$ & $1.417 \pm 0.083$ & $2.384 \pm 0.113$ \\
\hline Fungus infested & $52.803 \pm 0.921$ & $339.793 \pm 1.244$ & $118.993 \pm 0.639$ & $0.753 \pm 0.030$ & $2.245 \pm 0.036$ & $2.542 \pm 0.114$ \\
\hline Fungus infested $+60 \mathrm{mg} / \mathrm{ml} \mathrm{F}$ & $140.686 \pm 2.442$ & $607.777 \pm 1.841$ & $155.185 \pm 1.152$ & $0.575 \pm 0.015$ & $1.306 \pm 0.118$ & $1.811 \pm 0.087$ \\
\hline Healthy $+60 \mathrm{mg} / \mathrm{ml} \mathrm{F}$ & $63.023 \pm 0.563$ & $472.510 \pm 1.127$ & $131.843 \pm 0.865$ & $0.154 \pm 0.035$ & $1.347 \pm 0.142$ & $1.766 \pm 0.118$ \\
\hline Healthy + gresiofulvin treated & $34.707 \pm 0.859$ & $302.797 \pm 1.455$ & $101.447 \pm 0.866$ & $0.609 \pm 0.026$ & $1.615 \pm 0.087$ & $1.698 \pm 0.085$ \\
\hline $\begin{array}{c}\text { Fungus infested + gresiofulvin } \\
\text { treated }\end{array}$ & $31.677 \pm 2.084$ & $408.707 \pm 1.429$ & $96.703 \pm 0.895$ & $0.588 \pm 0.057$ & $1.602 \pm 0.005$ & $1.650 \pm 0.089$ \\
\hline
\end{tabular}

Table 4: Studies on the effect of $50 \%$ aq. ethanolic extract and bioactive sample on catalase super oxide dismutase activity in Pisum sativum L. seeds

\begin{tabular}{|c|c|c|c|c|c|c|}
\hline \multirow[t]{2}{*}{ Treatment sets } & \multicolumn{3}{|c|}{ Catalase activity } & \multicolumn{3}{|c|}{ Super Oxide Dismutase activity } \\
\hline & after $24 \mathrm{~h}$ & after $48 \mathrm{~h}$ & after $72 \mathrm{~h}$ & after $24 \mathrm{~h}$ & after $48 \mathrm{~h}$ & after $72 \mathrm{~h}$ \\
\hline Healthy & $0.183 \pm 0.004$ & $0.232 \pm 0.019$ & $0.073 \pm 0.007$ & $1006.663 \pm 8.135$ & $1066.00 \pm 3.786$ & $872.667 \pm 2.728$ \\
\hline Fungus infested & $0.242 \pm 0.037$ & $0.323 \pm 0.018$ & $0.083 \pm 0.007$ & $1081.667 \pm 3.087$ & $1199.667 \pm 3.087$ & $1229.667 \pm 3.919$ \\
\hline Fungus infested $+60 \mathrm{mg} / \mathrm{ml} \mathrm{F}$ & $0.305 \pm 0.008$ & $0.142 \pm 0.024$ & $0.057 \pm 0.018$ & $894.000 \pm 3.253$ & $1254.000 \pm 4.770$ & $1004.633 \pm 3.435$ \\
\hline Healthy $+60 \mathrm{mg} / \mathrm{ml} \mathrm{F}$ & $0.247 \pm 0.026$ & $0.040 \pm 0.012$ & $0.075 \pm 0.009$ & $993.327 \pm 2.721$ & $1304.333 \pm 4.586$ & $901.330 \pm 2.960$ \\
\hline Healthy + gresiofulvin treated & $0.318 \pm 0.028$ & $0.097 \pm 0.015$ & $0.130 \pm 0.035$ & $811.663 \pm 2.390$ & $1163.997 \pm 2.954$ & $1333.300 \pm 4.073$ \\
\hline $\begin{array}{c}\text { Fungus infested }+ \text { gresiofulvin } \\
\text { treated }\end{array}$ & $0.272 \pm 0.006$ & $0.040 \pm 0.012$ & $0.080 \pm 0.012$ & $764.833 \pm 2.024$ & $979.000 \pm 2.179$ & $981.330 \pm 4.203$ \\
\hline
\end{tabular}

\section{RESULTS AND DISCUSSION}

Table 1 represent general screening of petroleum ether, chloroform and $50 \%$ aqueous ethanolic extract against the fungus selected. Result revealed $50 \%$ aqueous ethanolic extract was found to be active against the fungus. From Table 2 and 3, it could be inferred that infestation of Pisum sativum seeds with Fusarium oxysporum caused reduction in the activities of amylase, protease and dehydrogenase enzymes. Administration of $50 \%$ aqueous ethanolic extract of Clitoria increased the enzyme activities appreciably leading towards control. In all the three cases, the extract and the purified sample showed higher potentiality than that off gresiofulvin. Table 3 and 4 depicts the antifungal effect of $50 \%$ aqueous ethanolic extract in relation to the activities of the stress enzymes catalase, peroxidase and superoxide dismutase. Results in all the three cases indicated sharp rise in the enzyme activities upon fungal infestation of Pisum seeds by Fusarium oxysporum. Presoaking the seeds with $50 \%$ aqueous ethanolic extract of Clitoria and the purified bioactive sample retarded the activities of the stress enzymes. The antifungal efficiency of the leaf extract and purified sample in terms of antifungal activity was also higher than gresiofulvin.

\section{CONCLUSION}

Hence from the above results it can be inferred that the crude $50 \%$ aqueous leaf extract of Clitoria ternatea L. showed antifungal activity in relation to the activities of the studied 
enzymes. Fungal infestation resulted in decrease in amylase, protease and dehydrogenase activity in the respective sets which were overcome in the extract treated sets. In the same way, fungal infestation induced increased activity of the stress enzymes were lowered by the extract treatment. The extract helped to maintain the normal activity level of the enzymes in the fungus infested seed sets compared to that of the control sets. So it can be said that $C$. ternatea L. may be used as a crop protectant of Pisum sativum seeds against Fusarium oxysporum infestation.

\section{ACKNOWLEDGEMENT}

The authors are grateful to Department of Botany, University of Kalyani, Kalyani, West Bengal, India for providing the laboratory facilities and University Grant Commission for financial assistance.

\section{REFERENCES}

1. Alkofahi A, Batshoun R, Owais W and Najib N. Biological activity of some Jordanian, medicinal plant extracts. Fitoterapia 1996; 68 Suppl 5: 435.

2. Banerjee SK, Chakravarti RN. Taraxerol from Clitoria ternatea, Bull Calcutta School Trop Med 1963; 11: 106-107.

3. Banerjee SK, Chakravarti RN. Taraxerone from Clitoria ternatea, Bull Calcutta School Trop Med 1964; 12: 23.

4. Joshi SS, Shrivastava RK, Shrivastava DK. Chemical examination of Clitoria ternatea Seeds, Journal of American Oil Chemical Society 1981; 58 Suppl 6: 714-715. http://dx.doi.org/10.1007/BF02899459

5. Tiwari RD, Gupta RK. Chemical examination of the oil from the seeds of Clitoria tematea Linn. Journal of Oil Technology Association of India 1957; 13: 9-13.

6. Yoganarasimhan SN. Medicinal Plant of India, Bangalore, India, Interline Publishing Co 2000; 2: 146-147.

7. Sinha A. Studies on the unsaponifiable matter of the seeds of Clitoria ternatea Linn. And isolation of $\gamma_{\text {sitosterol, Proceedings of the National }}$ Academy of Sciences 1960; 29: 23-26.

8. Sinha, A. Mucilage from the leaves of Clitoria ternatea. Proceedings of the Institution of Chemists. India 1960; 32: 228-231.

9. Osborn RW, Samblanx GW De, Thevissen K, Goderis I, Torrekens S, Van Leuven F. Isolation and characterization of plant defensins from seeds of Asteraceae, Fabaceae, Hippocastanaceae and Saxifragaceae, FEBS Letters 1995; 368: 257-262. http://dx.doi.org/10.1016/00145793(95)00666-W
10. Naeem A, Ahmed E, Khan RH. An alternate high yielding purification method for Clitoria ternatea lectin, International Journal of Biological Macro molecules 2007; 41: 481-486. http://dx.doi.org/10.1016 /j.ijbiomac.2007.05.006

11. Naeem A, Haque S, Khan RH. Purification and Characterization of a Novel B-D-Galactos I d es - Specific Lectin from Clitoria ternatea, The Protein Journal 2007; 26 Suppl 6: 403. http://dx.doi.org/10.1007 /s10930-007-9080-5

12. Kordali S, Cakir A, Mavi H, Yildirim, Kilic A. Screening of chemical composition and antifungal, antioxidant activities of the essential oils from three Turkish Artimisia species. J. Agric. Food. Chem 2005; 53 : 1408-1416. http://dx.doi.org/10.1021/jf0516538

13. Fick NG, Qualset CO. Generic control of Endosperm amylase activity and gibberellins responses standard height and short statured wheat. Proceedings of National Academy of Science 1975; 72: 892-5. http://dx.doi.org/10.1073/pnas.72.3.892

14. Kahn AA, Faust MA. Effects of growth retardants on amylase production in germinating Barley seed. Physiol Plant 1967; 20: 673-81. http://dx.doi.org/10.1111/j.1399-3054.1967.tb07209.x

15. Snell FD, Snell CT Snell. Colorimetric methods of analysis. Vol. IV AAA. Van Nostrand Reinhold Co., New York; 1971. p. 7-145.

16. Biswas AK, Choudhury MA. Differential behavior of the Flag leaf of intact rice plant during aging. Biochem and Physiol Pflanz 1978; 173: 220-228.

17. Rudrapal AB, Basu RN. Physiology of hydration-dehydration treatments in the maintenance of seed viability in wheat. Indian J Exp Biol 1979; 17: 768-71.

18. Chance B, Maehly AC. Assay of catalase and peroxidase, Methods Enzymol 1955; 2: 764-75. http://dx.doi.org/10.1016/S00766879(55)02300-8

19. Kar M, Mishra D. Catalase, Peroxidase and Poly phenol oxidase activities during rice leaf senescence. Plant Physiol 1976; 57 Suppl 2: 315-19. http://dx.doi.org/10.1104/pp.57.2.315

20. Biswas AK, Choudhury MA. Bio chemic and Physiologie der Pflanzen 1978; $173: 220$

21. Asada K, Takahashi M, Nagate M. Assay and inhibitors of spinach superoxide dismutase. Agric Biol Chem 1974; 38: 471-73. http://dx. doi.org/10.1271/bbb1961.38.471

Cite this article as:

Das Neela and Chatterjee Padma. Antifungal effect of Clitoria ternatea L. leaf extract on seeds of Pisum sativum $\mathrm{L}$. in relation to the activities of some enzymes. Int. J. Res. Ayurveda Pharm. 2014;5(1):99-101 http://dx.doi.org/ $10.7897 / 2277-4343.05120$ 